\title{
Marine engine seating on polymer-metal chocking
}

\begin{abstract}
Traditional systems of marine engine seating on metal and polymer chocks have been discussed and a new way of engine seating on polymer-metal chocks, of author's own design has been presented as to such background. The author's own designed chocks have been patent protected since 24.07.2000, patent number 192120 issued to Bohaterów Westerplatte Naval Academy in Gdynia. The chocks were designed to set the engines and other aggregates on the foundation. They ensure an appropriate alignment of the engine against the crankshaft power takeoff systems. The results of the tests carried out on the chocks have been presented proving that they meet the strength parameters required by the manufacturers of marine engines and comply with the regulations of the classification societies.
\end{abstract}

Key words: combustion engine, marine engine, seating engine

\section{Posadawianie silników w silowniach okrętów na podkładkach polimerowo-metalowych}

$W$ artykule przedstawiono tradycyjne sposoby posadawiania silników okrętowych na podkładkach metalowych $i$ polimerowych oraz zaprezentowano nowy sposób posadawiania silników na opracowanych przez autora podktadkach polimerowo-metalowych, chronionych od 24.07.2000 r. patentem nr 192120, udzielonym Akademii Marynarki Wojennej im. Bohaterów Westerplatte w Gdyni. Podkładki stuża do ustawiania silników i mechanizmów na fundamentach, zapewniaja uzyskanie wymaganego $w$ dokumentacji położenie silnika względem urządzenia odbierającego energię w postaci ruchu obrotowego. Przedstawiono wyniki badań podkładek, dowodzace, że spetniaja one parametry wytrzymatościowe wymagane przez producentów silników i przepisy towarzystw klasyfikacyjnych.

Słowa kluczowe: silnik spalinowy, siłownia okrętowa, posadawianie silników

\section{Traditional Engine Setting on the Foundations in the Engine Rooms}

In order to reduce a difficult and time consuming alignment of large load bearing surfaces of the setting points of the engine frame or other aggregates as well as the foundation shelves, an engine or an aggregate is usually set on the foundations through rigid metal chocking. Another purpose that the chocks serve is the precise alignment of the engine or the aggregate against a given base (the axis of the propeller shaft or the generator of the ship).

The contact surfaces of the chocks must precisely fit the load bearing surfaces of the engine or the aggregate and its foundations. This can be obtained through scraping of the contact surfaces with hand or mechanical (electric or pneumatic) scrapers (scraper width 6-30 mm, stroke 6-15 $\mathrm{mm}$, to scrape the material by $0.05-0.4 \mathrm{~mm}$ ), until $3-5$ spots of ink during the ink test are obtained in the square area of $25 \times 25 \mathrm{~mm}[1]$.

During the ship's operation the temperature of the chocks remains on the level of $60-80^{\circ} \mathrm{C}$ depending on the engine power output. Due to thermal deformation and the vibrations a slackening of the initial tightness of the foundation bolts and a slackening of the chock contact area with the frame setting points and the foundation shelves takes place. This makes it easy for humidity to penetrate the contact surface and may lead to corrosion-based damage even though the surfaces have protective layers. Due to the corrosion-based damage of the contact surfaces of the chocks the precision of their alignment against the load bearing points of the engine and the foundation occurs, hence during a conventional

\section{Tradycyjne posadawianie silników na fundamentach w silowni}

W celu ograniczenia trudnego, żmudnego dopasowywania dużych powierzchni nośnych stóp silnika i półek fundamentów, silnik posadawia się zwykle na fundamencie przez sztywne podkładki stalowe. Drugim celem stosowania podkładek jest konieczność dokładnego ustawienia silnika lub urządzenia okrętowego względem określonej bazy, np. linii wałów okrętu, prądnicy itp.

Powierzchnie przylegania podkładek muszą być dokładnie dopasowane do powierzchni nośnych silnika i ich fundamentów. Uzyskuje się to przez skrobanie przylegających powierzchni za pomocą płaskich skrobaków ręcznych lub mechanicznych (szerokość skrobaka 6-30 mm, suw 6-15 mm, do zebrania naddatku materiału 0,05-0,4 mm), $\mathrm{z}$ napędem elektrycznym lub pneumatycznym tak długo, aby przy sprawdzaniu tuszu uzyskać $3-5$ plam tuszu w polu kwadratu o bokach $25 \times 25 \mathrm{~mm}$ [1].

Podczas eksploatacji okrętu w obszarze podkładek utrzymuje się temperatura $60-80^{\circ} \mathrm{C}$, zależnie od mocy silnika. Wskutek odkształcenia cieplnego i wibracji silnika następuje spadek napięcia wstępnego śrub fundamentowych i rozluźnienie styku podkładek ze stopami silnika i półkami fundamentu. Ułatwia to dostęp wilgoci do powierzchni styku i powoduje powstawanie uszkodzeń korozyjnych. Wskutek uszkodzeń korozyjnych powierzchni przylegania podkładek zmienia się jakość ich dopasowania do powierzchni nośnych silnika i fundamentu i stąd przy tradycyjnej naprawie podkładki trzeba wymienić i ponownie żmudnie dopasować do naprawionych powierzchni nośnych silnika i fundamentu. 
repair the chocks have to be replaced and the whole aligning process must be repeated all over again. In the case of the main engine and the generator engine the chock replacement may be necessary if the co-linearity of the engine and the propellers is compromised. Again, the chocks must be precisely aligned to the repaired load bearing surfaces of the engine and the foundation.

Apart from the high costs the disadvantage of such a seating of the engines and other aggregates on the foundations is the rigidity of the chocks insufficiently damping the vibrations and the necessity to apply large tightening torques (up to 10 times the engine weight) to the foundation bolts in order to increase the contact area between the chocks, the load bearing points of the engine and the foundation as well as to prevent the chocks from displacing as a result of vibration. As the tests have shown [2] even if the surface is flat after polishing at a nominal pressure of $2.38 \mathrm{MPa}$ only $0.25 \%$ of the nominal surface is in contact - Fig. 1 . The static friction coefficient of steel to steel amounts to approximately only 0.1 and hence, there exists a danger of chock displacement due to engine vibration when the foundation bolts are slackened. This could lead to a lower accuracy in the engine-shaft alignment.
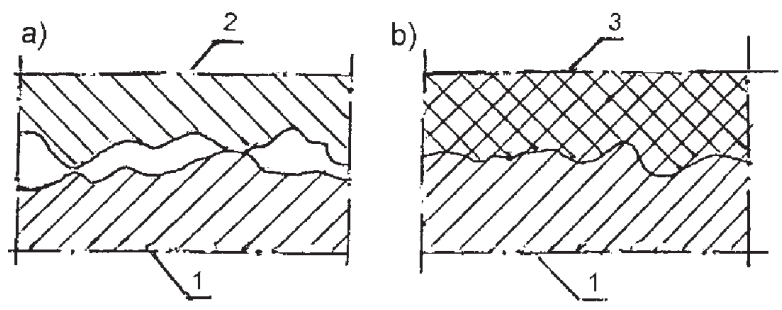

Fig. 1. Schematics of the contact with the steel chock foundation (a) and cast polymer (b): 1 - foundation, 2 - steel chock, 3 - polymer chock [2] Rys. 1. Schemat styku z fundamentem podktadki stalowej (a) i odlanej z polimeru (b): 1 -fundament, 2 - podkładka stalowa, 3 -podkładka z polimeru [2]

A reduction of the work and time consumption related to the engine setting on the foundation can be obtained through the application of steel adjustable chocks (Fig. $2 b$ and $c)$. However, because of certain disadvantages such chocks did not become overly popular. At the end of the 1960 s of the last century the engineers began to seat the engines and other aggregates on cast polymer chocks [1]. These chocks do not have the disadvantages of the rigid steel chocks and do not require a painstaking and time consuming alignment to the load bearing surfaces of the engine frame and the upper plate of the foundation in the engine room. The seating of the engines and other mechanisms on the foundations must be approved by a governing classification society. In this respect, the classification societies adopt appropriate regulations [1-4].
W odniesieniu do silnika głównego i silnika zespołu prądotwórczego potrzeba wymiany podkładek może powstać też przy utracie wymaganej współosiowości silnika względem linii wałów okrętu lub prądnicy. I wtedy też trzeba żmudnie dopasowywać nowe podkładki do naprawionych powierzchni nośnych silnika i fundamentu.

Oprócz dużych kosztów wadą takiego posadawiania na fundamentach silników jest sztywność podkładek, niewystarczająco tłumiących wibrację silnika, i konieczność stosowania dużych sił (o wartości do 10-krotnego ciężaru silnika) napięcia śrub fundamentowych celem powiększenia styku podkładek z powierzchniami nośnymi silnika i fundamentu oraz zapobieżeniu przesuwania się podkładek na fundamencie przy wibracji silnika. Jak wykazały badania [2], nawet przy kontakcie płaskich powierzchni wykończająco szlifowanych, przy nominalnym docisku 2,38 MPa tylko 0,25\% nominalnej powierzchni styka się z sobą (rys. 1). Współczynnik tarcia spoczynkowego stali ze stalą wynosi tylko ok. 0,1, a stąd przy osłabionych napięciach śrub fundamentowych silnika istnieje niebezpieczeństwo przesuwania się podkładek przy wibracji silnika, co może spowodować zmniejszenie dokładności osiowania silnika z linią wałów.

Zmniejszenie pracy i czasu posadawiania silnika na fundamencie można uzyskać dzięki zastosowaniu stalowych podkładek nastawialnych (rys. 2b i c), lecz ze względu na ich wady nie znalazły one szerszego zastosowania w praktyce. W tej sytuacji z końcem lat sześćdziesiątych XX w. zaczęto posadawiać silniki i mechanizmy okrętowe na podkładkach stanowiących odlewy polimeru [1], które nie mają większości wad sztywnych podkładek stalowych, a przede wszystkim nie wymagają żmudnego dopasowywania do powierzchni nośnych stóp silnika i górnej płyty fundamentu w siłowni okrętu. Posadawianie na fundamentach silników i mechanizmów okrętowych musi uzyskać aprobatę właściwego towarzystwa klasyfikacyjnego. W tej sprawie towarzystwa klasyfikacyjne wydają odpowiednie przepisy [1-4]. a)

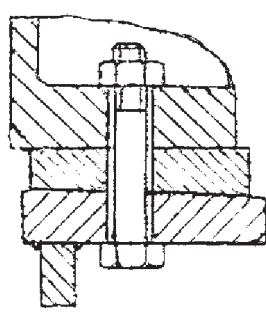

b)

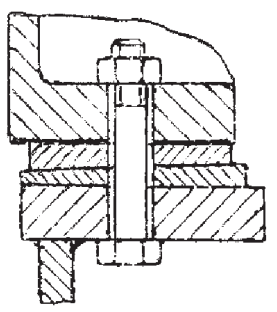

c)

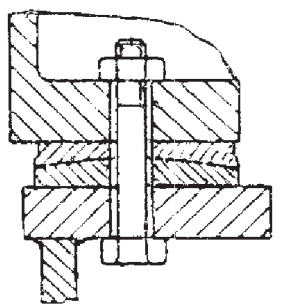

Fig. 2. Engine setting on the foundation through steel chocks: a) wedge chock, b), c) adjustable chocks

Rys. 2. Posadowienie silnika na fundamencie przez podkładki stalowe: a) podkładka klinowa, b), c) podktadki nastawialne

\section{Polimery na podkładki silników i urządzeń okrętowych}

Polimery na podkładki nośne silników zestawiono w tab. 1. Wszystkie polimery są dopuszczone do stosowania przez kilka największych towarzystw klasyfikacyjnych, a niektóre 


\section{Polymers for the Engine and Aggregate Chocking}

The polymers for the engine and aggregate chocks have been listed in Table 1. All the polymers have been approved for application by several largest classification societies and some of them have been approved by the US Army (Chockfast Orange, Devcon P) [5, 6]. The times of polymer wear mają atesty armii USA (Chockfast Orange, Devcon P) $[5,6]$. Podane w tabeli 1 czasy na zużycie polimeru w temperaturze $20^{\circ} \mathrm{C}$ dotyczą porcji 500 g polimeru. W niższej temperaturze i przy mniejszych porcjach polimeru będą one dłuższe. Czas do utwardzenia polimeru w stopniu umożliwiającym jego obróbkę mechaniczną też odnosi się do porcji $500 \mathrm{~g}$ polimeru. Przy większych porcjach polimeru będzie on krótszy.

Table 1. Selected polymers used for chock production [1]

Tabela 1. Wybrane polimery na podktadki nośne

\begin{tabular}{|c|c|c|c|c|c|c|c|c|c|}
\hline \multirow{2}{*}{\multicolumn{2}{|c|}{ Property/wlaściwości }} & \multirow{2}{*}{$\begin{array}{l}\text { Unit/jed- } \\
\text { nostka }\end{array}$} & \multicolumn{7}{|c|}{ Name of polymer/nazwa polimeru } \\
\hline & & & $\begin{array}{l}\text { CHOCKFAST } \\
\text { ORANGE }\end{array}$ & $\begin{array}{c}\text { EPOCAST } \\
36 \\
\end{array}$ & EPY & K-153 & $\begin{array}{c}\text { BELZONA } \\
1121\end{array}$ & $\begin{array}{l}\text { CHESTER } \\
\text { SUPER SL }\end{array}$ & DEVCON P \\
\hline \multicolumn{2}{|l|}{ State/postać } & - & liquid/ptyn & $\begin{array}{l}\text { liquid/ } \\
\text { plyn }\end{array}$ & $\begin{array}{l}\text { liquid/ } \\
\text { ptyn }\end{array}$ & $\begin{array}{l}\text { liquid/ } \\
\text { ptyn }\end{array}$ & $\begin{array}{l}\text { paste/ } \\
\text { pasta }\end{array}$ & $\begin{array}{l}\text { paste/ } \\
\text { pasta }\end{array}$ & $\begin{array}{l}\text { paste/ } \\
\text { pasta }\end{array}$ \\
\hline $\begin{array}{l}\text { Base to hardener ratio/ } \\
\text { stosunek bazy do utwar- } \\
\text { dzacza }\end{array}$ & $\begin{array}{c}\text { By weight/wagowo } \\
\text { By volume/objęto- } \\
\text { ściowo }\end{array}$ & - & - & - & - & $\begin{array}{c}100: 1 \\
284: 11\end{array}$ & $\begin{array}{c}1,2: 1 \\
1: 1\end{array}$ & $\begin{array}{c}2,5: 1 \\
2: 1\end{array}$ & $\begin{array}{c}4,3: 1 \\
3: 1\end{array}$ \\
\hline \multicolumn{2}{|c|}{ Wear time in $20^{\circ} \mathrm{C} /$ czas na zuzycie $w 20^{\circ} \mathrm{C}$} & $\mathrm{m}$ & 60 & 1,59 & - & 42 & 35 & 20 & 25 \\
\hline $\begin{array}{l}\text { Full mechanical load } \\
\text { after hardening in tempe- } \\
\text { rature of/petne obciażenie } \\
\text { mechaniczne po utwar- } \\
\text { dzeniu } w \text { temperaturze }\end{array}$ & $\begin{array}{l}10^{\circ} \mathrm{C} \\
15^{\circ} \mathrm{C} \\
20^{\circ} \mathrm{C} \\
25^{\circ} \mathrm{C}\end{array}$ & $\mathrm{h}$ & $\begin{array}{l}- \\
48 \\
24 \\
-\end{array}$ & $\begin{array}{c}- \\
48 \\
28 \\
-\end{array}$ & $\begin{array}{c}- \\
48 \\
24 \\
-\end{array}$ & $\begin{array}{l}- \\
- \\
72 \\
-\end{array}$ & $\begin{array}{c}48 \\
27 \\
16 \\
9\end{array}$ & $\begin{array}{c}120 \\
- \\
48 \\
-\end{array}$ & $\begin{array}{l}- \\
- \\
16 \\
-\end{array}$ \\
\hline $\begin{array}{l}\text { Resistance to temperature } \\
\text { when/odporność na temp. }\end{array}$ & $\begin{array}{l}\mathrm{dry} / \text { sucho } \\
\text { wet/mokro }\end{array}$ & ${ }^{\circ} \mathrm{C}$ & $\begin{array}{l}80 \\
-\end{array}$ & 80 & 80 & $\begin{array}{l}60 \\
-\end{array}$ & $\begin{array}{c}200 \\
60\end{array}$ & $\begin{array}{c}180 \\
-\end{array}$ & $\begin{array}{c}175 \\
-\end{array}$ \\
\hline \multicolumn{2}{|l|}{ Density/gęstość } & $\mathrm{g} / \mathrm{cm}^{3}$ & 1,58 & - & 1,59 & - & - & 2,45 & 2,36 \\
\hline \multicolumn{2}{|c|}{ Tensile strength/wytrzymałość na rozciaganie } & $\mathrm{MPa}$ & 34 & 49 & 46 & - & - & - & 23 \\
\hline \multicolumn{2}{|c|}{ Resistance to pressure/wytrzym. na nacisk } & $\mathrm{MPa}$ & 131 & 164 & 169 & 160 & 88 & 146 & 130 \\
\hline \multicolumn{2}{|c|}{ Bending resistance/wytrzymałość na zginanie } & $\mathrm{MPa}$ & - & - & - & - & 58 & 92 & 53 \\
\hline \multicolumn{2}{|c|}{$\begin{array}{l}\text { Resistance to shear of the steel joints/wytrzyma- } \\
\text { tość na ścinanie zlaczy stali }\end{array}$} & $\mathrm{MPa}$ & 37 & - & 59 & 14 & 19,7 & 14,4 & 14,0 \\
\hline \multicolumn{2}{|l|}{ Impact resistance/udarność } & $\mathrm{J} / \mathrm{cm}^{2}$ & 210 & 170 & 210 & - & - & 94 & 54 \\
\hline \multicolumn{2}{|l|}{ Hardness/twardość } & - & B40 & B55 & B52 & - & - & R114 & Sh85 \\
\hline $\begin{array}{l}\text { Creeping in } 70^{\circ} \mathrm{C} \text { de- } \\
\text { pending on the clamping } \\
\text { tension/petzanie } w 70^{\circ} \mathrm{C} \\
\text { zalezinie od napręzeń } \\
\text { ściskających }\end{array}$ & $\begin{array}{c}3,4 \mathrm{MPa} \\
6,9 \mathrm{MPa} \\
13,8 \mathrm{MPa}\end{array}$ & $\mathrm{Mm}$ & $\begin{array}{c}0 \\
0,076 \\
0,178\end{array}$ & $\begin{array}{l}0,020 \\
0,024 \\
0,036\end{array}$ & $\begin{array}{l}0,011 \\
0,011 \\
0,015\end{array}$ & $\begin{array}{l}- \\
- \\
-\end{array}$ & $\begin{array}{l}- \\
- \\
-\end{array}$ & $\begin{array}{l}- \\
- \\
-\end{array}$ & $\begin{array}{l}- \\
- \\
-\end{array}$ \\
\hline
\end{tabular}

in the temperature of $20^{\circ} \mathrm{C}$ listed in the table refer to $500 \mathrm{~g}$ portions of the polymer. At lower temperatures and smaller portions of the polymer these times will extend. The time of polymer bonding to the extent enabling its mechanical processing also refers to $500 \mathrm{~g}$ portions of the polymer. At larger polymer portions the time will be reduced.

For the reasons of competition, there is not much information as to the composition of the polymers. It is yet known that the basic ingredient is the low particle content epoxy resin Epidian 5. All the polymers except polymer K-153 (filled with quartz dust) are, to a higher or lower extent filled with steel powders. Liquid polymers inevitably contain a solvent. Polymer K-153 used in the chocks probably contains 100 p.b.w. of epoxy resin ED-20, 40 p.b.w. of low particle content polyamide resin $Ł-18,15$ p.b.w. of dibutyl phthalate, 15 p.b.w. of quartz dust and 12 p.b.w.
Informacji o składnikach tych polimerów jest niewiele ze względu na konkurencję. Wiadomo jednak, że ich podstawowym składnikiem jest małocząsteczkowa żywica epoksydowa typu Epidian 5. Wszystkie polimery są w mniejszym lub większym stopniu napełnione proszkami stali, z wyjątkiem polimeru K-153, który jest napełniany pyłem kwarcowym. Polimery w postaci płynu niewątpliwie zawierają rozcieńczalnik. Polimer K-153 W zastosowaniu na podkładki nośne prawdopodobnie zawiera 100 cz.w. żywicy epoksydowej ED-20, 40 cz.w. małocząsteczkowej żywicy poliamidowej Ł-18, 15 cz.w. ftalanu dwubutylu, 15 cz.w. pyłu kwarcowego i 12 cz.w. trójetylenoczteroaminy. Porównanie polimerów na podkładki utrudnia także to, że ich właściwości fizyczne i mechaniczne producenci wyznaczali często różnymi metodami i w różnych warunkach. 
of triethylene fouramine. The comparison of the polymers is difficult as the manufacturers determined their physical and mechanical properties through different methods under different conditions.

The basic disadvantage of the polymer casts is their low strength and resistance to creeping which causes the slackening of the foundation bolts. This particular disadvantage is a stimulus for the search of new solutions eliminating this flaw and at the same time keeping the advantages of this type of seating. Such a search of new technologies has been undertaken in Naval Academy in Gdynia and, as a result, a new way of engine seating has been developed, as shown in Fig. 3, which is patent protected (patent number 192120 [7]. This new solution consists in placing (gluing in) metal plates, between the engine seating point and the shelf of the foundation, that are covered with layers of polymers on both sides, whose composition, consistency and density is selected in order to meet the required strength, temperature and compression parameters specified in the engine documentation as provided by the manufacturers and the regulations of the classification societies.

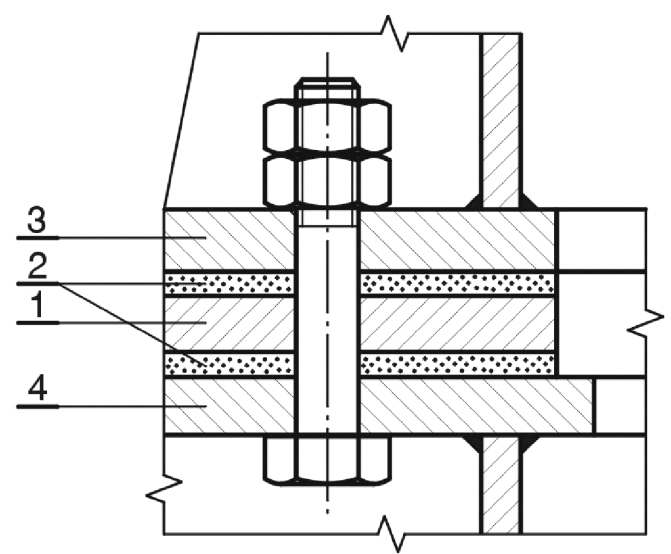

Fig. 3. Polymer metal chock developed by the Naval Academy: 1 - metal part, 2 - layers of polymer composition in the chock, 3 - engine seating point, 4 - foundation plate

Rys. 3. Podkładka polimerowo-metalowa według wynalazku: 1-część metalowa podkładki, 2 - warstwy kompozycji polimerów w podkładce, 3 - stopa silnika, 4-ptyta fundamentu

In order for the invention to be admitted by Polski Rejestr Statków (Polish Ship Register) for application in ship building and ship repair, tests were undertaken to obtain the strength parameters of the polymer-metal chocks, particularly the compression resistance of the relatively thin layers of the composition of polymers in the chocks and the influence of the tightness of the foundation bolts and the thickness of the polymer layers on the resistance of the chocks to the force that pushes the engine from the foundation. The results have been presented in the further part of this paper.

\section{Materials and Test Methodology of the Metal- Polymer Chocks}

The metal parts of the sample glued joints were made from $16 \mathrm{~mm}$ thick metal sheet PN-81/H-9216 and a St3S (according to PN-88/H-84020) steel bar of $30 \mathrm{~mm}$ in diam-
Zasadniczą wadą odlewów z kompozycji polimerów jest mała wytrzymałość i odporność na pełzanie, które powoduje relaksacje napięcia śrub fundamentowych. Wada ta jest przesłanką do poszukiwań nowych rozwiązań, które ją wyeliminują przy pozostawieniu pozytywnych cech tego rodzaju posadawiania. Badania takie podjęto w Akademii Marynarki Wojennej w Gdyni i w ich rezultacie udało się opracować, chroniony patentem nr 192120 [7], nowy sposób posadawiania przedstawiony na rys. 3 , który polega na umieszczeniu (wklejeniu) pomiędzy stopą silnika i półką fundamentu metalowych podkładek, obustronnie obłożonych warstwami kompozycji polimerów o składzie, konsystencji i gęstości dobranej pod kątem spełnienia minimalnych parametrów wytrzymałościowych, temperaturowych i nacisku, określonych w dokumentacji silnika wystawionej przez producenta i przepisach towarzystw klasyfikacyjnych.

W celu dopuszczenia przez Polski Rejestr Statków stosowania wynalazku przy budowach i remontach okrętów podjęto badania dotyczące wyznaczenia parametrów wytrzymałościowych podkładek polimerowo-metalowych według wynalazku, a w pierwszym rzędzie wytrzymałości na ściskanie stosunkowo cienkich warstw kompozycji polimerów w podkładkach oraz wpływu wartości napięcia śrub fundamentowych i grubości warstwy kompozycji polimerów na wytrzymałość podkładek na działanie siły spychającej silnik $\mathrm{z}$ fundamentu.

\section{Materiały i metoda badań podkladek metalowo-polimerowych}

Części metalowe próbnych złączy klejonych wykonano z blachy o grubości $16 \mathrm{~mm}$ PN-81/H-9216 oraz z pręta o średnicy $30 \mathrm{~mm}$ ze stali St3S według PN-88/H-84020. Jako chemoutwardzalną kompozycję polimerów zastosowano produkt Belzona 1111B o: wytrzymałości na ściskanie 105,5 $\mathrm{N} / \mathrm{mm}^{2}$ według ASTM D-695, wytrzymałości na rozciąganie $63,4 \mathrm{~N} / \mathrm{mm}^{2}$ według ASTM D-790, module Younga $\mathrm{E}=1850$ $\mathrm{N} / \mathrm{mm}^{2}$ według ASTM D-695, adhezji do stali $20,7 \mathrm{~N} / \mathrm{mm}^{2}$ według ASTM D-1000 i skurczu utwardzania $\varepsilon_{\mathrm{o}}<0,025 \%$ według DOD-C-324176A [6].

Powierzchnie elementów stalowych złączy do sklejenia rozwinięto przez obróbkę pilnikami do czystego metalu. Parametr Ra, wyznaczony według PN-73/M-04251, w poszczególnych złączach doczołowych zawierał się $\mathrm{w}$ granicach 1,05-3,16 $\mu \mathrm{m}$, średnio wynosił 1,93 $\mu \mathrm{m}$, a w złączach zakładkowych zawierał się w granicach 2,23-3,08 $\mu \mathrm{m}$, średnio wynosił $2,74 \mu \mathrm{m}$. Następnie powierzchnie do sklejenia odtłuszczono rozpuszczalnikiem, a potem zmieszano bazę kompozycji z utwardzaczem chemicznym i tak przygotowaną kompozycją polimerów sklejono złącza z lekkim dociskiem na pryzmie traserskiej. Do badań wytrzymałości podkładek na ściskanie zastosowano walcowe próbki utwardzonej kompozycji polimerów oraz doczołowe złącza klejone, jak na rys. 4.

Doczołowe złącza klejone wykonano z odcinków pręta ze stali St3s o średnicy $30 \mathrm{~mm}$. Po utwardzeniu kompozycji złącza przetoczono na średnicę do $=20 \mathrm{~mm}$. Powierzchnia czynna złączy ściskanych wynosiła $314 \mathrm{~mm}^{2}$. 
eter. As a chemical bonded composition of polymers Belzon $1111 \mathrm{~B}$ was applied with the compression resistance 105,5 $\mathrm{N} / \mathrm{mm}^{2}$ according to ASTM D-695, tensile strength 63.4 $\mathrm{N} / \mathrm{mm}^{2}$ according to ASTM D-790, Young's modulus $\mathrm{E}=$ $=1850 \mathrm{~N} / \mathrm{mm}^{2}$ according to ASTM D-695, adhesion to steel $20.7 \mathrm{~N} / \mathrm{mm}^{2}$ according to ASTM D-1000 and solidifying contraction $\varepsilon_{0}<0.025 \%$ according to DODC-324176A [6].

The surface of the steel elements of the joints was processed with metal files. Parameter Ra, obtained according to PN-73/M-04251 in individual head-to-head joints fell within $1.05-3.16 \mu \mathrm{m}$, and on average amounted to 1.93 $\mu \mathrm{m}$, and in the overlapping joints $-2.23-3.08 \mu \mathrm{m}$, on average amounted to $2.74 \mu \mathrm{m}$. Subsequently, the surfaces to be glued were degreased with a solvent and, then, the base of the composition was mixed with a chemical hardener and with such a composition of polymers the joints were glued applying a light clamp on a block.

For the compression resistance tests cylindrical samples of a hardened composition of polymers and glued head-tohead joints were used as shown in Fig. 4.

Head-to-head glued joints were made from steel St3S $30 \mathrm{~mm}$ bars. Upon hardening the joints were turned into a diameter of $\mathrm{d}_{\mathrm{o}}=$ $=20 \mathrm{~mm}$. The active surface of the compressed joints was $314 \mathrm{~mm}^{2}$.

The compression tests were performed on an MTS machine. Up to the pressure of 300 $\mathrm{N} / \mathrm{mm}^{2}$ applied by the machine the shrink of the steel parts of the joints $(\Delta \mathrm{h})$ did not exceed $0.03 \mathrm{~mm}$ and was neglected in the test results analysis.

For the tests of the resistance of the chocks to displacement against the foundation, overlapping glued joints of own design were used as shown in Fig. 5. They reflect the actual shape of the chocks as per the patented invention and can be stressed during the tests in the same way as it occurs during the engine operation.

After 24 hours of hardening of the composition of polymers in the ambient temperature, in the sample joints two bores were drilled of $\mathrm{d}=12 \mathrm{~mm}$ in diameter for the bolts that couple the steel elements of the joints. These bolts simulated the actual foundation bolts used during the seating of the engine on the foundation.

The sample overlapping glued joints of the first series of tests at a complex load state, with the polymer thickness of $5 \mathrm{~mm}$, were randomly divided into three groups, six joints in each. In the first group of joints the coupling bolts were tightened with a torque wrench to the value of $\mathrm{F}_{\mathrm{y}}=700 \mathrm{~N}$, which corresponds to the chock load reflecting that of the engine itself. In the second group of joints the tightness of the bolts was $\mathrm{F}_{\mathrm{y}}=4200 \mathrm{~N}$, which corresponds to the chock load reflecting six times the weight of the engine and in the third group the tightness of the bolts was $\mathrm{F}_{\mathrm{y}}=7700 \mathrm{~N}$, which
Próby ściskania przeprowadzono na maszynie wytrzymałościowej MTS. Do uzyskania ciśnienia $300 \mathrm{~N} / \mathrm{mm}^{2}$ w cylindrze maszyny wytrzymałościowej skrócenie części stalowych złączy $(\Delta \mathrm{h})$ nie przekraczało $0,03 \mathrm{~mm}$ i było pomijane w analizie wyników prób ściskania.
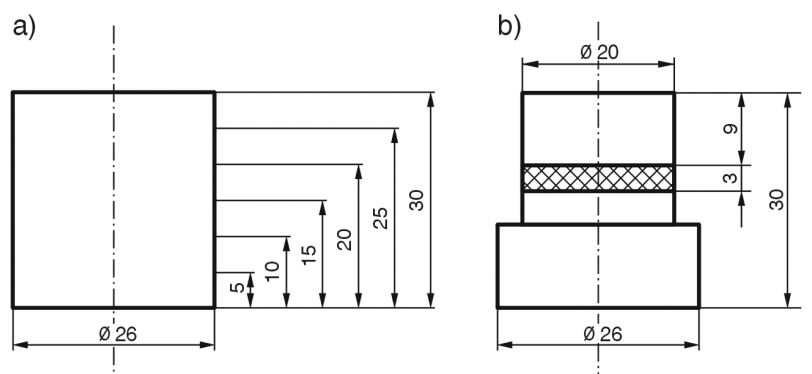

Fig. 4. Samples for the compression tests: a - hardened composition of polymers, variable height of samples, $\mathrm{b}$ - head-to-head glued joint

Rys. 4. Próbki do prób ściskania: a) utwardzonej kompozycji polimerów, zmienna wysokość próbek, b) doczołowego złącza klejonego

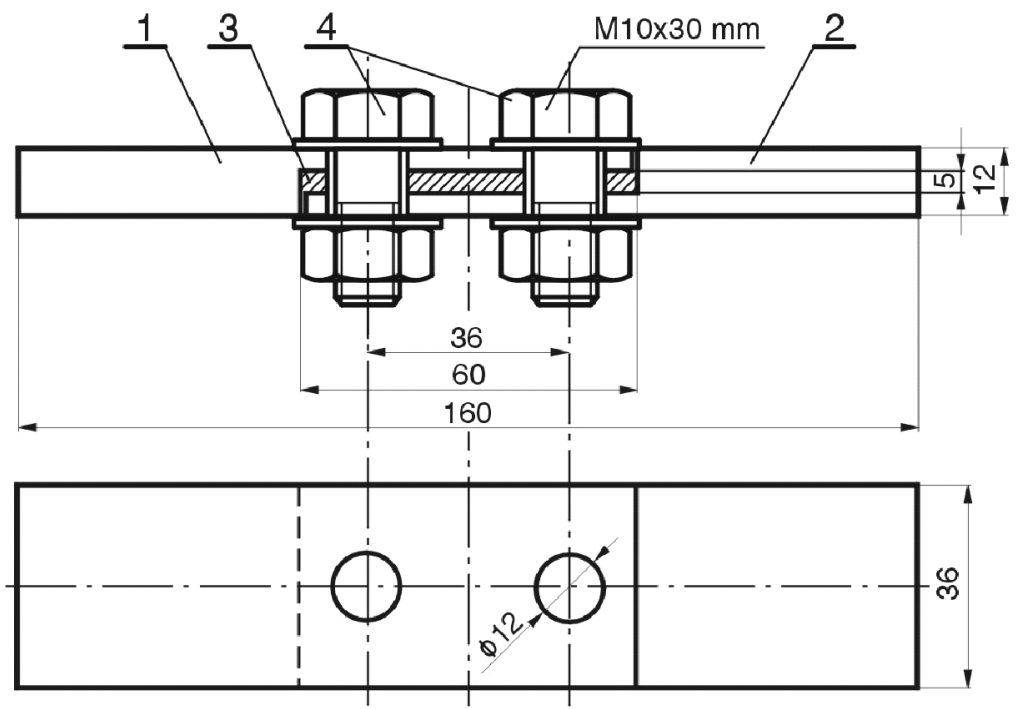

Fig. 5. A sample of an overlapping joint glued with a composition of polymers: 1,2-metal parts of the joint, 3 - a composition of polymers, 4 - bolts M10 $\times 30 \mathrm{~mm}$

Rys. 5. Próbka zakładkowego złącza klejonego kompozycją polimerów: 1, 2-części metalowe złącza, 3 - kompozycja polimerów, 4 -śruby $M 10 \times 30 \mathrm{~mm}$

Do badań odporności podkładek na przesuwanie po fundamencie zastosowano, własnej koncepcji, zakładkowe złącza klejone (rys. 5). W miarę dokładnie oddają one rzeczywisty kształt podkładek według wynalazku i można je obciążać w czasie próby dokładnie w taki sam sposób, jaki występuje w czasie eksploatacji silnika.

Po 24 godzinach utwardzania kompozycji polimerów w temperaturze otoczenia, w złączach próbnych wiercono po dwa otwory o średnicy $\mathrm{d}=12 \mathrm{~mm}$ pod śruby łączące elementy stalowe złącza. Śruby te symulowały rzeczywiste śruby fundamentowe stosowane przy ustawianiu silnika na fundamencie.

Próbne zakładkowe złącza klejone pierwszej serii badań przy złożonym stanie obciążenia, o grubości warstwy kom- 
corresponds to the chock load reflecting eleven times the weight of the engine. The tests assumed, according to the Germanischer Lloyd regulations [3], that the load exerted on the composition of polymers in the chock cannot exceed $0.7 \mathrm{~N} / \mathrm{mm}^{2}$.

The engine is set on the foundation complying with the requirements of the classification society [3] through metal or plastic chocks. The chocks may be of variable thickness along the engine axis, which results from the admissible variations in the plate position against the power takeoff systems. The engine is fixed to the foundation with bolts. The number and the tightening torques of the bolts is determined by the engine manufacturer so that the bolts can withstand the axial force resulting from the engine angular acceleration. It is assumed that with the metal chocks the sum of the foundation bolt tightening torques should amount to ten times the weight of the engine and with the plastic chocks - five times the weight of the engine [8]. The tightness of the foundation bolts should also generate a static friction of the chock to avoid a displacement of the engine against the foundation during hull lurch [11], Fig. 6.

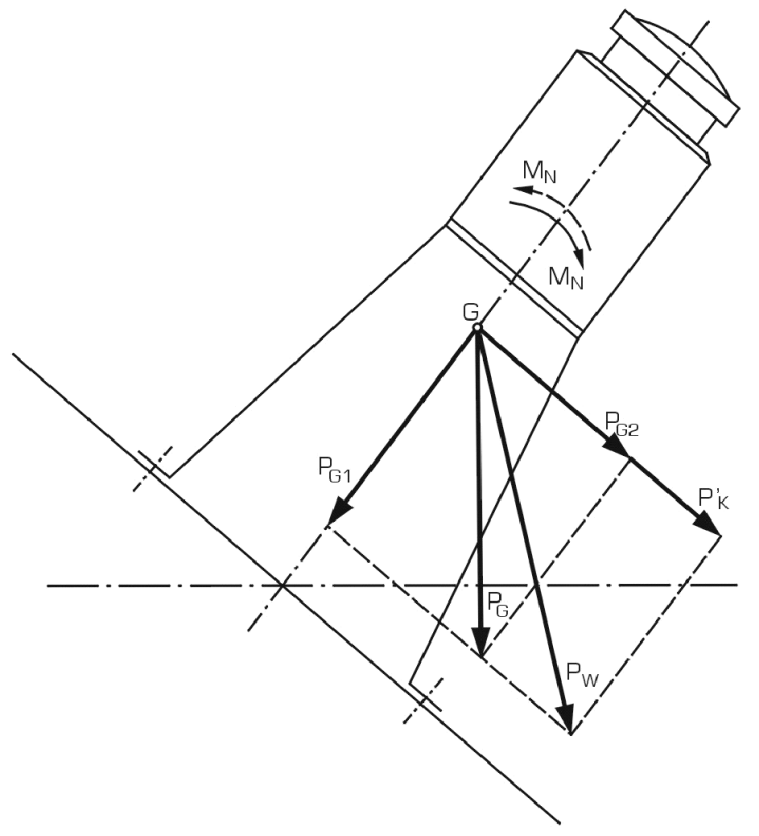

Fig. 6. Forces acting on the engine during a hull lurch [10]: $\mathrm{G}$ - center of gravity of the engine, $\mathrm{P}_{\mathrm{G}}$ - engine weight, $\mathrm{P}_{\mathrm{G} 1}, \mathrm{P}_{\mathrm{G} 2}-$ components of the engine weight, $\mathrm{P}_{\mathrm{k}}$ - inertia force $\mathrm{P}_{\mathrm{w}}$ - resultant of the forces $\mathrm{P}_{\mathrm{G}}$ and $\mathrm{P}_{\mathrm{k}}$ Rys. 6. Sity działajace na silnik podczas przechytu okrętu: $G$-środek ciężkości silnika, $P_{G}$ - ciężar silnika, $P_{G 1}, P_{G 2}-$ składowe ciężaru silnika, $P_{k}-$ siła bezwładności, $P_{w}-$ wypadkowa sit $P_{G} i P_{k}[10]$

The lurch results from the amplitude of the ship's sway on the wave, static action of the wind perpendicular to the ship symmetrical axis as well as the wind gusts acting in the same direction.

The thickness of the patented chocks is changed through the modification of the polymer layer thickness. In order to determine the influence of the thickness of the chock polymer pozycji polimerów $5 \mathrm{~mm}$, podzielono losowo na trzy grupy, w każdej po sześć złączy. W pierwszej grupie złączy śruby łączące napięto kluczem dynamometrycznym do wytworzenia siły ściskającej złącze $F_{y}=700 \mathrm{~N}$, która odpowiada umownie obciążeniu podkładki samym ciężarem ustawianego silnika. $\mathrm{W}$ drugiej grupie złączy napięcie śrub wynosiło $\mathrm{F}_{\mathrm{y}}=4200 \mathrm{~N}$, co odpowiada umownie obciążeniu podkładki sześciokrotnym ciężarem ustawionego silnika, a w trzeciej grupie złączy napięcie śrub wynosiło $\mathrm{F}_{\mathrm{y}}=7700 \mathrm{~N}$, co odpowiada umownie jedenastu ciężarom ustawianego silnika. Przyjęto przy tym, zgodnie z przepisami Germanischer Lloyd [3], że obciążenie kompozycji polimerów w podkładce od ciężaru ustawionego silnika nie może przekraczać $0,7 \mathrm{~N} / \mathrm{mm}^{2}$.

Silnik ustawia się na fundamencie spełniającym wymagania towarzystwa klasyfikacyjnego [3] poprzez podkładki metalowe lub z tworzywa sztucznego. Podkładki mogą mieć zmienną grubość na długości silnika, co wynika z dopuszczalnych odchyleń położenia płyty fundamentu od osi urządzenia odbierającego energie obrotów silnika. Silnik mocuje się do fundamentu śrubami. Liczbę i napięcie śrub fundamentowych określa producent silnika, tak aby mogły przenieść siłę osiową wynikającą z przyspieszenia ruchu silnika. Przyjmuje się umownie, że przy podkładkach metalowych suma napięcia śrub fundamentowych powinna wynosić 10 ciężarów silnika, a przy podkładkach z tworzyw sztucznych -5 ciężarów silnika [8]. Napięcie śrub fundamentowych powinno także wytworzyć siłę tarcia spoczynkowego podkładki zapobiegającą przesunięciom silnika na fundamencie podczas przechyłów kadłuba okrętu na fali [11] (rys. 6).

Przechyły boczne kadłuba okrętu wynikają z amplitudy poprzecznego kołysania kadłuba na fali, statycznego działania wiatru o kierunku prostopadłym do płaszczyzny symetrii okrętu oraz działających w tym samym kierunku porywów wiatru.

Grubość podkładek według patentu zmienia się przez zmianę grubości warstw kompozycji polimerów. W celu rozpoznania wpływu grubości warstwy kompozycji polimerów na wytrzymałość $\mathrm{R}_{\mathrm{rt}}$ podkładek według patentu wykonano drugą serię 9 złączy próbnych, jak w pierwszej serii badań, lecz o grubościach warstwy kompozycji polimerów: 1, 2 i $3 \mathrm{~mm}$. Zastosowano ponownie napięcia śrub łączących: 700 N, 4200 N i 7700 N. Tak więc każda grubość warstwy kompozycji polimerów i każde napięcie śrub łączących były reprezentowane przez jedno złącze próbne.

Po dostatecznym utwardzeniu ( 7 dni w temperaturze otoczenia) próbne złącza klejone rozciągano-ścinano na maszynie wytrzymałościowej MTS w zakresie sił od 0 do $95 \mathrm{kN}$. Badane złącza próbne ustawiano na maszynie wytrzymałościowej za pomocą kątownika traserskiego i sprawdzano położenie siły zerowej. Takie osadzanie złączy próbnych w uchwytach maszyny wytrzymałościowej zapewniało osiowe działanie siły rozciągającej; nie wprowadzało innych sił mogących zniekształcać wynik próby rozciągania. Przebieg rozciągania rejestrowano co $1 \mathrm{~ms}$ przy założonej drodze tłoka $1 \mathrm{~mm}$ przebytej w czasie 1 minuty. Zniszczenie złączy próbnych następowało częściowo przez ścięcie w 
layers on the chock strength $\mathrm{R}_{\mathrm{rt}}$ another series of 9 sample joints was made, similarly to the first series, only the thickness of the polymer layers was: $1 \mathrm{~mm}, 2 \mathrm{~mm}$ and $3 \mathrm{~mm}$. The tightening torques of the bolts were: $700 \mathrm{~N}, 4200 \mathrm{~N}$ and $7700 \mathrm{~N}$. Hence, each of the polymer layers and each value of the tightening torque were represented by a single sample joint.

After a sufficient hardening (7 days in the ambient temperature) the sample glued joints underwent a tensile strength and shear resistance tests on an MTS machine within the force range from 0 to $95 \mathrm{kN}$. The tested sample joints were set on the MTS machine with an angle bracket and the zero force position was checked. Such a setting of the sample joints in the brackets ensured forces were acting that could distort the test results. The course of the tensile tests was recorded every $1 \mathrm{~ms}$ at the assumed piston stroke of $1 \mathrm{~mm}$ covered in the time of 1 minute. The destruction of the sample joints occurred partly through shear in the steel polymer joint and partly through tensile failure or shear of the polymer layers. The example graph of the course of the test has been shown in Fig. 7 [1]. The tensile force until destruction $F_{x}$, related to the surface under the shear force $\mathrm{S}_{\mathrm{y}}$ has been assumed to be the destructive stretching-shearing stress $R_{r t}$.

The load distributions on the sample joint during the stretching-shearing test have been shown in Fig. 7. The graph also presents a hypothetical distribution of bending forces along the length of the overlapping element of the sample joint, confirmed with the strength analysis of the glued joints presented in the paper [5].

As shown in Fig. 8 the sample joint is loaded with two compressing forces $\mathrm{F}_{\mathrm{y}}$, generated by the tightening of the bolts

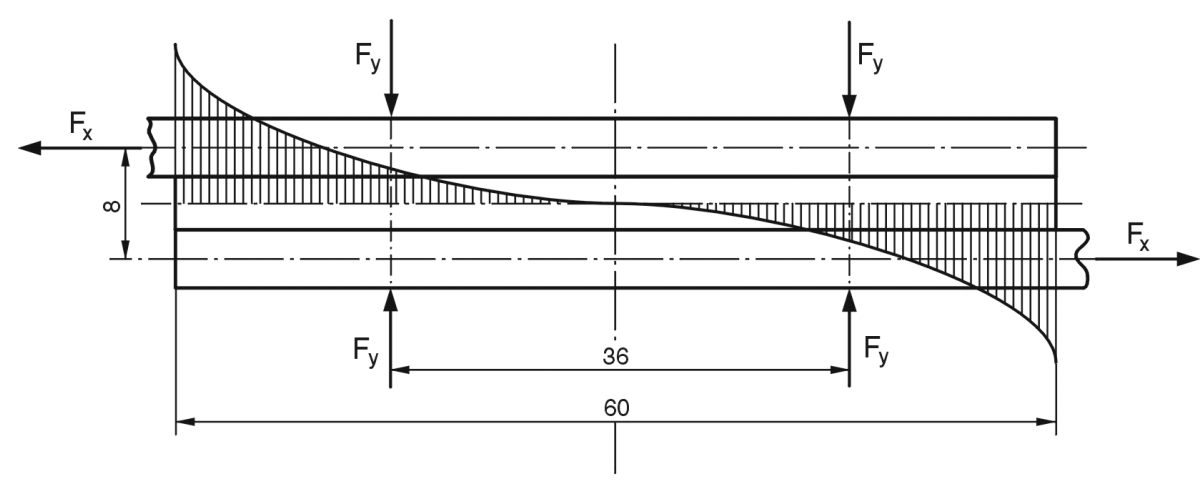

Fig. 8. The load distribution over the joint during the stretching-shearing test: $\mathrm{F}_{\mathrm{x}}$ - stretching force, $\mathrm{F}_{\mathrm{y}}$ - compressing force of the bolt

Rys. 8. Stan obciążenia złącza w czasie próby rozciagania-ścinania: $F_{x}$ - siła rozciagania złącza, $F_{y}$ - siła ściskania złącza napięciem śruby ścinanej powierzchni $\mathrm{S}_{\mathrm{y}}$. the axial vector of the tensile force; no additional

powierzchni rozdziału stal-kompozycja polimerów, a częściowo przez rozerwanie lub ścięcie warstwy kompozycji polimerów. Dla przykładu, na rys. 7 przedstawiono wykres rozciągania-ścinania zakładkowego złącza próbnego [1]. Jako niszczące naprężenie rozciągające-tnące $\mathrm{R}_{\mathrm{rt}}$ przyjęto siłę rozciągania do zniszczenia złącza $\mathrm{F}_{\mathrm{x}}$, odniesioną do

Stan obciążenia złącza próbnego w czasie próby rozciągania-ścinania przedstawiono na rys. 7. Na rysunku przed-

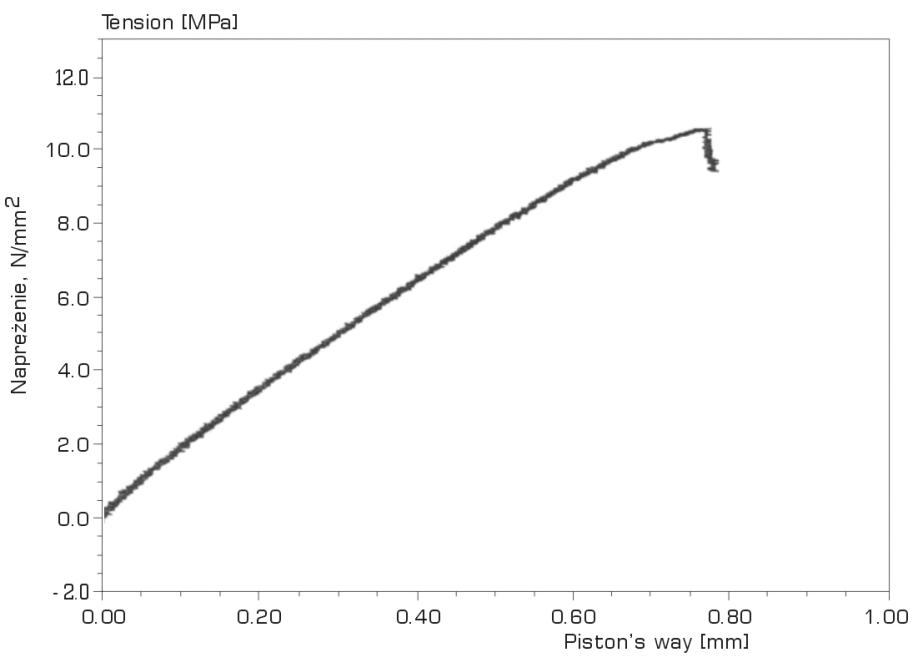

Fig. 7. Graph showing the stretching-shearing of the overlapping sample joint. Tightening torque of the bolts $\mathrm{F}_{y}=4200 \mathrm{~N}$. Resistance to stretching-shearing $\mathrm{R}_{\mathrm{rt}}=10.5 \mathrm{~N} / \mathrm{mm}^{2}[13]$

Rys. 7. Wykres rozciagania-ścinania zakładkowego złącza próbnego. Napięcie śrub Rys. 7. Wyczacych $F_{y}=4200 \mathrm{~N}$. Wytrzymałość na rozciaganie-ścinanie $R_{r t}=10,5 \mathrm{~N} / \mathrm{mm}^{2}[13]$

stawiono też hipotetyczny rozkład naprężeń zginających na długości zakładki złącza próbnego, potwierdzony analizą wytrzymałości złączy klejonych podaną w pracy [5].

Jak widać na rys. 8 , złącze próbne jest obciążone dwoma siłami ściskającymi $F_{y}$, wytworzonymi napięciem śrub łączących (symulujących śruby fundamentowe) oraz parą sił rozciągających $\mathrm{F}_{\mathrm{x}}$ działającą na ramieniu $\mathrm{r}$ o wartości wyznaczonej grubością warstwy kompozycji polimerów. W złączach pierwszej serii badań $\mathrm{r}=8,5 \mathrm{~mm}$. Działanie pary sił $\mathrm{F}_{\mathrm{x}}$ na ramieniu $r$ powoduje moment zginający złącze o wartości $\mathrm{M}=\mathrm{F}_{\mathrm{x}} \cdot \mathrm{r}$, który często pomija się w obliczeniach wytrzyma-

(simulating the foundation bolts) and the pair of tensile forces $F_{x}$ exerted on " $r$ " having a value determined by the thickness of the polymer layer. In the joints of the first series of tests $\mathrm{r}=8.5 \mathrm{~mm}$. The action of the pair of forces $\mathrm{F}_{\mathrm{x}}$ on " $\mathrm{r}$ " results in a bending moment of the joint of $\mathrm{M}=\mathrm{F}_{\mathrm{x}} \cdot \mathrm{r}$, which is fre- łości złącza, mimo iż ujawnia się w mechanice niszczenia złącza; zniszczenie złącza rozpoczyna się w miejscach występowania największych naprężeń zginających i wyraża się odrywaniem warstwy kompozycji polimerów od części stalowych złącza. 
quently neglected in the calculations of the joint strength, even though it does come up in its destruction mechanics; the destruction of the joint begins in the spots of the highest bending stresses and is expressed through the tensile failure between the polymer layers and the metal parts of the joint.

\section{Test Results}

6 trials of the head-to-head glued joints have been performed of the polymer thickness $3.0 \mathrm{~mm}$. An example graph of the compression has been shown in Fig. 9.

As we can see in Fig. 9, when compressing the joints the stress of $300 \mathrm{~N} / \mathrm{mm}^{2}$ and the deformation of $1.5 \%$ of the polymer layer was not exceeded. The deformation of the metal parts of the joints did not exceed $0.03 \%$ and was neglected in the test results analysis.

The assumed stress and deformation boundaries during the compression tests enabling only the plasticity boundaries $\sigma_{\mathrm{d} 0.2}$ to be determined. The plasticity boundary ranged from $246 \mathrm{~N} / \mathrm{mm}^{2}$ to $286 \mathrm{~N} / \mathrm{mm}^{2}$, on average $269 \mathrm{~N} / \mathrm{mm}^{2}$, hence, it was 2.55 times higher than $\sigma_{\mathrm{d} 0.2}$ given by the manufacturer solely for the composition of the polymers.

After the trial in none of the joints were cracks in the Belzon 1111B composition of polymers detected.

For the analysis of the resistance to stretching-shearing Rrt of the joints of the first series the results of the tests on three joints were rejected as they clearly varied from the

Table 2. Forces and stresses in the sample joints of individual groups

Tabela 2. Siły obciążajace i naprężenia w złączach próbnych poszczególnych grup

\begin{tabular}{|c|c|c|c|c|c|c|c|}
\hline $\begin{array}{c}\text { Group of joints/ } \\
\text { grupa ztaczy }\end{array}$ & $\begin{array}{c}\text { Bolt tightening torque } \\
\mathrm{F}_{y}, \mathrm{~N} / \text { napięcie śrub }\end{array}$ & $\begin{array}{c}\sigma_{\mathrm{y}} \\
\mathrm{N} / \mathrm{mm}^{2}\end{array}$ & $\begin{array}{c}\mathrm{F}_{\mathrm{x}} \\
\mathrm{N}\end{array}$ & $\begin{array}{c}\sigma_{\mathrm{x}} \\
\mathrm{N} / \mathrm{mm}^{2}\end{array}$ & $\begin{array}{c}\sigma_{\mathrm{xy}} \\
\mathrm{N} / \mathrm{mm}^{2}\end{array}$ & $\begin{array}{c}\mathrm{R}_{\mathrm{rt}} \\
\mathrm{N} / \mathrm{mm}^{2}\end{array}$ \\
\hline 1 & 1400 & 0.72 & 2131.2 & 7.4 & 7.44 & 7.4 \\
\hline 2 & 8400 & 4.34 & 2995.2 & 10.4 & 11.27 & 14.68 \\
\hline 3 & 15400 & 7.96 & 3024.0 & 10.5 & 13.13 & 21.51 \\
\hline
\end{tabular}

results of the outstanding test objects in a given group. The average resistance to stretching-shearing $\mathrm{R}_{\mathrm{rt}}$ amounted to: $7.4 \mathrm{~N} / \mathrm{mm}^{2}$ for the joints of the first group, $10.4 \mathrm{~N} / \mathrm{mm}^{2}$ for the joints of the second group and $10.5 \mathrm{~N} / \mathrm{mm}^{2}$ for the joints of the third group - Table 2 .

The average values of the tensile - shearing forces and corresponding stresses in individual groups of joints were determined for the stretched area of $\mathrm{S}_{\mathrm{r}}=12(36-12)=288 \mathrm{~mm}^{2}$ and the compressed or sheared area of $\mathrm{S}_{\mathrm{s}}=1974 \mathrm{~mm}^{2}$. In order to simplify the calculations it was assumed that the compressed and sheared areas are equal.

The values of the shearing stresses $\tau_{\mathrm{xy}}$ were obtained from the formula: razy większa od wartości $\sigma_{\mathrm{d} 0,2}$ podanej przez producenta dla samej kompozycji polimerów. Po próbie, w żadnym złączu nie stwierdzono pęknięć w warstwie kompozycji polimerów Belzona 1111B. Do analizy wytrzymałości na rozciąganieścinanie $\mathrm{R}_{\mathrm{rt}}$ złączy pierwszej serii badań odrzucono wyniki prób trzech złączy, jako wyraźnie odstające od wyników prób pozostałych złączy w danej grupie. Średnia wytrzymałość na rozciąganie-ściskanie $\mathrm{R}_{\mathrm{rt}}$ wynosiła: $7,4 \mathrm{~N} / \mathrm{mm}^{2}$ dla złączy pierwszej grupy, $10,4 \mathrm{~N} / \mathrm{mm}^{2}$ dla złączy drugiej grupy i $10,5 \mathrm{~N} / \mathrm{mm}^{2}$ dla złączy trzeciej grupy (tab. 2).

Średnie wartości sił rozciągających i ścinających oraz odpowiadających im naprężeń w poszczególnych grupach złączy wyznaczono dla powierzchni rozciąganej złączy $\mathrm{S}_{\mathrm{r}}=12(36-12)=288 \mathrm{~mm}^{2}$ oraz powierzchni ściskanej lub ścina- 


$$
\tau_{x y}=\sqrt{\sigma_{x}^{2}+\sigma_{y}^{2}}
$$

The values of the stresses have been listed in Table 2 .

If we neglect the bending of the joints caused by the eccentric application of the tensile force, then during the stretching, the joints were loaded with: a tensile force $F_{x}$, compressing force $\mathrm{F}_{\mathrm{y}}$, resulting from the tension of the bolts connecting the metal elements and, consequently, the shearing force of the joint $\mathrm{T}_{\mathrm{xy}}$. In a two dimensional (flat) stress, following the M.T. Huber's hypothesis of deformation energy [12], the effort of the joint may be measured through the values of the reduced stress $\sigma_{\text {red }}$ obtained from the formula

$$
\sigma_{\text {red }}=\sqrt{\sigma_{x}^{2}+\sigma_{y}^{2}-\sigma_{x} \cdot \sigma_{y}+3 \cdot \tau_{x y}^{2}}
$$

The calculated values of $\sigma_{\text {red }}$ for the individual groups of sample joints have been listed in Table 1.

From formula (2) it results that the effort of the joints (Fig. 10) grows as the tension of the connecting bolts increases as is the case with the resistance to stretching-shearing $R_{r t}$, which is confirmed by the tests results - Fig. 10 .

The tension of the foundation bolts including the weight of the engine determine the force needed to displace the engine against the foundation. In order to determine this force the vertical load of the chocking is multiplied by the static friction coefficient. From the tests (Fig. 11) it results that the increase in the tension of the connecting bolts above $4200 \mathrm{~N}$ (which is generally assumed to be 6 times the weight of the engine) does not yield a significant increase in the joint strength $\mathrm{R}_{\mathrm{rt}}$. It is, thus, possible to limit the tension of the foundation bolts to the value of 5 times the weight of the engine.

The number and the tension of the foundation bolts when seating the engine on the foundations are determined by the manufacturer and should collectively give a force that is higher than the vertical force resulting from the acceleration of the engine speed. The advancement in the engine design aims at reducing this force, which enables the reduction of the number and the tension of the foundation bolts and reduce the number of the side blockers that are an additional security against engine displacement. An example could be the Sulzer RTA-T engine [9] whose redesign led to a reduction of the chock surface by $29 \%$, the number of the foundation bolts from 54 to 22 and the number of the side blockers from 12 to 6 - Fig. 11 .

The results of the first series of tests were included in the second series of stretching-shearing tests. nej złączy $\mathrm{S}_{\mathrm{s}}=1974 \mathrm{~mm}^{2}$. Dla uproszczenia obliczeń przyjęto, że powierzchnie ścinana i ściskana złącza są sobie równe.

Wartości naprężeń tnących $\tau_{\mathrm{xy}}$ obliczono z wzoru (1).

Obliczone wartości naprężeń zestawiono w tab. 2.

Jeżeli pominie się zginanie złączy spowodowane mimośrodowym przyłożeniem siły rozciągającej, to w czasie rozciągania złącza były obciążone: siłą rozciągającą $\mathrm{F}_{\mathrm{x}}$, siłą ściskającą $F_{y}$, pochodzącą $z$ napięcia śrub łączących elementy stalowe złącza i wynikającą z nich siłą ścinającą złącze $\mathrm{T}_{\mathrm{xy}}$,

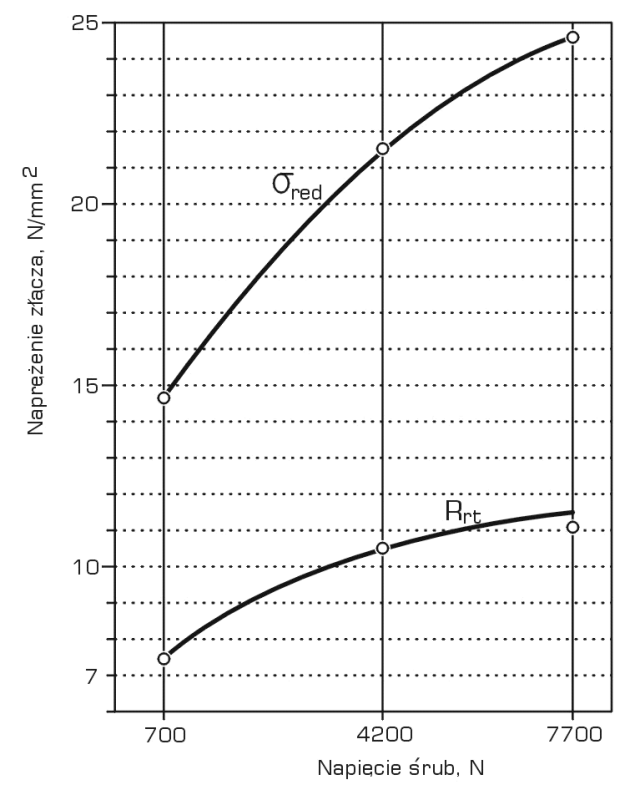

Fig. 10. Change of effort $\sigma_{\text {red }}$ and strength $\mathrm{R}_{\mathrm{rt}}$ of the joints along the increase of the bolt tension

Rys. 10. Zmiana wytężenia $\sigma_{r e d} i$ wytrzymałości $R_{r t}$ złączy ze zwiększeniem napięcia śrub

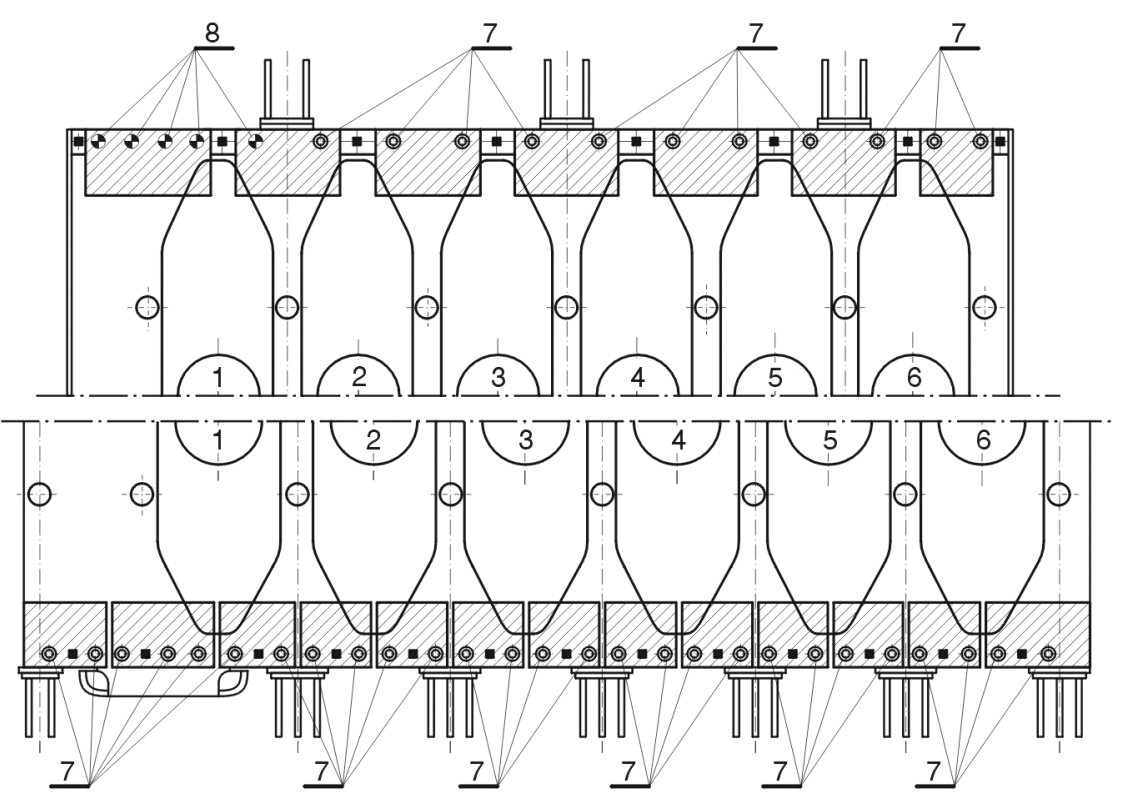

Fig. 11. Schematics of a seating of a 6 cylinder Sulzer RTA-T before redesign (lower) and after redesign (upper) [9]: 1-6-cylinders, 7 - oundation bolts, 8 - close fit foundation bolts

Rys. 11. Plan posadowienia 6-cylindrowego silnika Sulzer RTA-T przed rekonstrukcja (dót) i po rekonstrukcji (góra): 1-6-cylindry, 7-przelotowe śruby fundamentowe, 8-pasowane śruby fundamentowe 


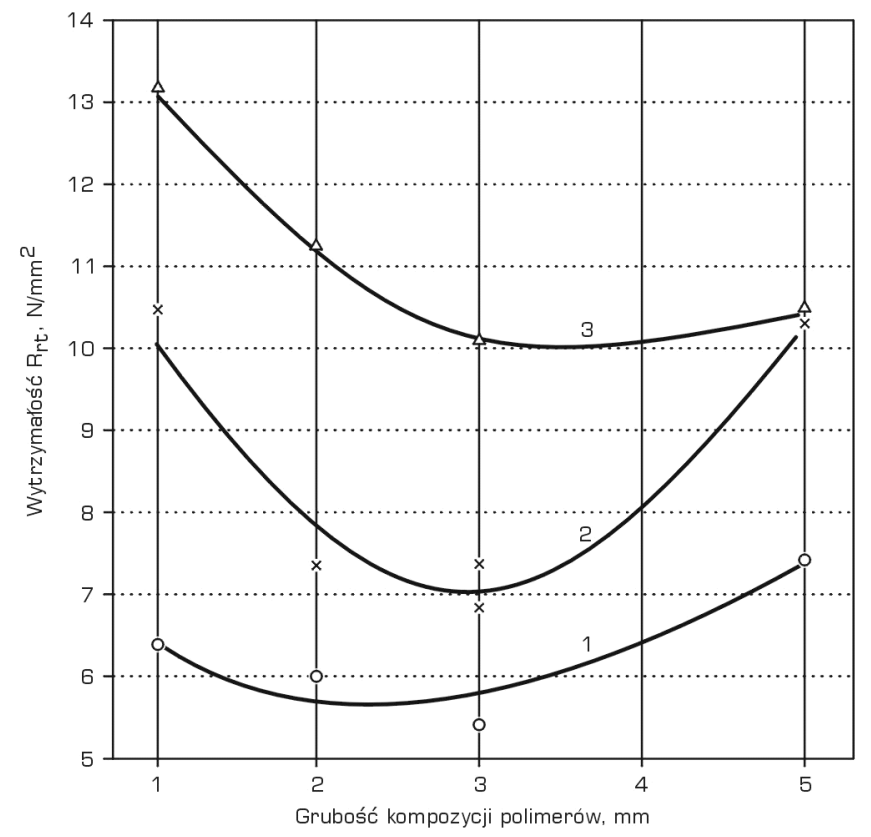

Fig. 12. Change in the resistance to stretching-shearing of the sample joints depending on the tension of the connecting bolts and the thickness of the layer of the composition of polymers. The strength of the joints with the bolts tightening torque: $1-700 \mathrm{~N}, 2-4200 \mathrm{~N}, 3-7700 \mathrm{~N}$

Rys. 12. Zmiana wytrzymałości na rozciaganie-ścinanie złączy próbnych zależnie od napięcia śrub łączacych i grubości warstwy kompozycji polimerów. Wytrzymałość złączy ze śrubami napiętymi siła: $1-700 \mathrm{~N}, 2-4200 \mathrm{~N}, 3-7700 \mathrm{~N}$

The results of the tests have been shown in Fig. 12 .

As we can see in Fig. 12 the lowest resistance to stretching-shearing showed the sample joints with the layer thickness of the polymers $3 \mathrm{~mm}$. The reduction of the thickness of the polymer layer renders the strength of the joints higher. The increase in the thickness of the polymer layer renders the strength of the joints higher but it is not as effective as the reduction of the polymer layer.

The smallest changes in the strength of the joints with the increase of the polymer thickness occurred for joints with the connecting bolts tightened with the torque of $700 \mathrm{~N}$. The biggest changes in the strength occurred for joints with the connecting bolts tightened with the torque of $4200 \mathrm{~N}$.

For technological considerations (paste consistency) the manufacturer does not recommend applying layers of Belzon 1111B polymers thinner than $3 \mathrm{~mm}$. In that case it seems that for the patented chocks, the application of Belzon 1111B polymer layers thicker than $3 \mathrm{~mm}$ can be recommended. Perhaps, after a certain level of dilution of the composition, chocks of lower thickness could be made, which, according to the tests results, will increase the resistance of the chocks to the displacing forces against the foundation.

The tests of the influence of the polymer layer thickness on the strength of the joints should be construed as a pilot project due to a small number of the tested joints. A continuation of the investigation is highly recommended.
Przy dwuwymiarowym (płaskim) stanie naprężenia, zgodnie z hipotezą energii odkształcenia postaciowego M.T.Hubera [12], wytężenie złącza można mierzyć wartością naprężenia zastępczego $\sigma_{\text {red }}$ obliczonego z wzoru (2).

Obliczone wartości $\sigma_{\text {red }}$ dla poszczególnych grup złączy próbnych zestawiono w tab. 2.

Z wzoru (2) wynika, że wytężenie złączy (rys. 10) zwiększa się ze zwiększeniem napięcia śrub łączących. Podobnie zwiększa się wytrzymałość na rozciąganieścinanie $\mathrm{R}_{\mathrm{rt}}$. Potwierdzają to wyniki badań (rys. 10).

Napięcie śrub fundamentowych łącznie z ciężarem silnika wyznaczają wartość siły potrzebnej do przesunięcia silnika na fundamencie. Do wyznaczenia tej siły pionowe obciążenie podkładek mnoży się przez współczynnik tarcia spoczynkowego. Z przeprowadzonych badań (rys. 11) wynika, że zwiększenie napięcia śrub łączących powyżej $4200 \mathrm{~N}$ (co umownie przyjęto, jako 6-krotny ciężar silnika) nie daje istotnego zwiększenia wytrzymałości złączy $\mathrm{R}_{\mathrm{rt}}$. Można więc, ze względu na utrzymanie silnika na fundamencie, ograniczyć napięcie śrub fundamentowych do wartości równej 5-krotnemu ciężarowi silnika.

Liczba i napięcie śrub fundamentowych przy ustawianiu silnika na fundamencie są określone przez producenta i powinny w sumie dać siłę większą od siły pionowej, wynikającej z przyspieszenia obrotów silnika. Rozwój konstrukcji silników zmierza do ograniczenia tej siły, co pozwala zmniejszyć liczbę i napięcie śrub fundamentowych oraz zmniejszyć liczbę stoperów bocznych, które stanowią dodatkowe zabezpieczenie przed przesunięciem się silnika na fundamencie. Przykładem może być silnika Sulzer RTA-T [9], którego przekonstruowanie pozwoliło zmniejszyć: powierzchnię oporową podkładek o $29 \%$, liczbę śrub fundamentowych z 54 na 22 i liczbę stoperów bocznych z 12 na 6 (rys. 11).

Do wyników prób rozciągania-ścinania złączy próbnych drugiej serii badań dołączono wyniki prób złączy pierwszej serii badań. Połączone wyniki prób złączy przedstawiono na rys. 12.

Najmniejszą wytrzymałość na rozciąganie-ścinanie wykazały złącza próbne o warstwach kompozycji polimerów grubości $3 \mathrm{~mm}$ (rys. 12). Zmniejszenie grubości warstwy kompozycji polimerów daje zwiększenie wytrzymałości złączy. Także zwiększenie grubości warstwy kompozycji polimerów daje zwiększenie wytrzymałości złączy lecz w mniejszym stopniu niż zmniejszenie grubości warstwy kompozycji polimerów.

Najmniejsze zmiany wytrzymałości złączy ze zwiększeniem grubości warstwy kompozycji polimerów wystąpiły w złączach ze śrubami łączącymi napiętymi siłą $700 \mathrm{~N}$. Największe zmiany wytrzymałości wystąpiły w złączach ze śrubami napiętymi siłą $4200 \mathrm{~N}$.

Ze względów technologicznych (konsystencja pasty) producent nie zaleca nakładania na przedmioty stalowe warstwy kompozycji polimerów Belzona 1111B o grubości poniżej $3 \mathrm{~mm}$. W tej sytuacji wydaje się, że w podkładkach 


\section{Conclusions}

The following conclusions can be made in light of the compression strength tests results of the hardened composition of Belzon 1111B polymers (compliant with PN-EN-ISO 4385:1996) and the tests of the head-to-head glued joints as well as the resistance tests to stretching-shearing of the overlapping joints glued with the composition of Belzon 1111B polymers simulating the patented chocks (patent number 192120) for marine engine and aggregate seating on the foundations, particularly in the ship engine rooms:

1. The applied Belzon 1111B composition showed that the compression resistance was higher than the minimum guaranteed by the manufacturer $\left(\sigma_{\mathrm{d} 2}=115 \mathrm{~N} / \mathrm{mm}^{2}\right.$, manufacturer's $-\sigma_{\mathrm{d} 2}=105 \mathrm{~N} / \mathrm{mm}^{2}$ ).

2. The compression resistance of the head-to-head joints is higher than the resistance of the sole composition of polymers.

3. At the tightening torques of the foundation bolts equaling 5 times the weight of the engine the chocking sufficiently prevents the engine from any displacement against the foundation.

Artykut recenzowany według patentu można zalecić stosowanie warstw kompozycji polimerów Belzona 1111B o grubości powyżej $3 \mathrm{~mm}$. Być może, po pewnym rozcieńczeniu kompozycji można będzie wykonywać podkładki o mniejszej grubości warstw kompozycji, co, zgodnie z wynikami badań, zwiększy wytrzymałość podkładek na siły mogące je przesuwać na fundamencie.

Badania wpływu grubości warstwy kompozycji polimerów na wytrzymałość złączy należy uznać za pilotowe, ze względu na małą liczbę badanych złączy. Wydaje się, że trzeba kontynuować te badania.

\section{Wnioski}

Uzyskane wyniki badań wytrzymałości na ściskanie utwardzonej kompozycji polimerów Belzona 1111B według PN-EN-ISO 4385:1996 oraz doczołowych złączy klejonych i wytrzymałości na rozciąganie-ścinanie zakładkowych złączy klejonych, kompozycją polimerów Belzona 1111B, symulujących podkładki według Patentu nr 192120 do posadowienia silników i mechanizmów na fundamentach, zwłaszcza w siłowniach okrętów, pozwalają stwierdzić, że:

1. Zastosowana kompozycja Belzona 1111B wykazała wytrzymałość na ściskanie większą od minimalnie gwarantowanej przez producenta $\left(\sigma_{\mathrm{d} 2}=115 \mathrm{~N} / \mathrm{mm}^{2}\right.$, a producent gwarantował $\sigma_{\mathrm{d} 2}=105 \mathrm{~N} / \mathrm{mm}^{2}$ ).

2. Wytrzymałość na ściskanie złączy doczołowych jest większa niż wytrzymałość na ściskanie samej kompozycji polimerów.

3. Przy napięciu śrub fundamentowych równym 5. ciężarom ustawianego silnika podkładki wystarczająco zabezpieczają przed przesunięciem się silnika na fundamencie.

\section{Bibliography/Literatura}

[1] Piaseczny L.: Technologia polimerów w remontach okrętów. Wydawnictwo Gdańskiego Towarzystwa Naukowego, Gdańsk 2002.

[2] Grudziński K., Jaroszewicz W.: Posadawianie maszyn i urządzeń na podkładkach fundamentowych odlewanych z tworzywa EPY. ZAPOL, Szczecin 2002

[3] Germanischer Lloyd. Regulation for seating propulsion plants. Hamburg. April 1995.

[4] Polski Rejestr Statków. Przepisy klasyfikacji i budowy statków morskich. Część II. Kadłub. Gdańsk 2007.

[5] Zaczek Z.: Studium wytrzymałości statycznej i odporności na działanie środowiska klejonych połączeń metali i laminatów szklanych. Zbiór prac WSMW, nr 38A. Gdynia 1973.

[6] Masek R.: Co to jest kompozyt? Materiały konferencji naukowo-technicznej „Belzona na pokładzie”. Łeba 8-0.03.2007 r. Belse. Bielsko-Biała 2007.

[7] UP RP, Patent nr 192120: Sposób posadowienia silników i mechanizmów na podstawach fundamentowych. Warszawa 2006.

[8] Wilson M.: Marine epoxy resin chock. Marine Technology, vol. 21. No 1, January 1984.
[9] Design features and performance Sulzer RTA-T. Technology Review, April 1998.

[10] Piotrowski I., Witkowski K.: Okrętowe silniki spalinowe. Trademar. Gdynia 1996.

[11] Polski Rejestr Statków. Przepisy klasyfikacji i budowy statków morskich. Część IV. Stateczność i niezatapialność. Gdańsk 2007.

[12] Jakubowicz A., Orłoś Z.: Wytrzymałość materiałów, wyd. 5. WNT, Warszawa 1978.

[13] Bruski S., Świątek K.: Protokoły z badań wytrzymałościowych złączy kompozytowo-metalowych. AMW, Gdynia 2008.

Prof. Leszek Piaseczny, DSc., DEng. - Professor in the Mechanical-Electric Faculty at Naval University of Gdynia.

Prof. dr. hab. inż. Leszek Piaseczny - profesor na Wydziale Mechaniczno-Elektrycznym Akademii Marynarki Wojennej w Gdyni.

e-mail: piaseczny@ptnss.pl 